\title{
THE USE OF VIDEO AS MEDIA IN TEACHING WRITING DESCRIPTIVE TEXT
}

\author{
Guswar Dwifadjrin', Mundriyah Y Pamungkas² \\ ${ }^{1}$ IKIP Siliwangi \\ ${ }^{2}$ IKIP Siliwangi \\ ${ }^{1}$ guswardwifadjrin@student.ikipsiliwangi.ac.id, ${ }^{2}$ mundriyahpamungkas@ikipsiliwangi.co.id
}

\begin{abstract}
Writing is one of the skills which must be mustered in learning English. However, many students het difficulties in learning writing. The objectives of the research entitled " The used of video as media in teaching writing descriptive text" were to found out: 1) the implementation of the scenario in teaching English writing descriptive texts in seventh grade using video as media. 2) Students responses in learning descriptive text using video as media. In conducting this research, it was used a descriptive qualitative research design to describe the result of the research. The subject of the research was grade VII of junior high school in Padalarang, consit 20 students. The results of this study indicated that the implementation in teaching is done according to the scenario which was prepared by the researchers. The responses of the students based on the questionnaires showed that teaching learning proses using video was effective. Students had high enthusiasm, they did not feel monotonous, and they were motivated. From the result of assessment, most of the students had difficulties in writing English because they had poor grammar, lack of vocabulary, and poor understanding of mechanics in writing. In addition, the students had less experience because they were not accustomed to using English in writing. After learning using video as media, the student could overcome their difficulties eventhough there was few students that not understand grammar use, vocabulary, and mechanics in the final project.
\end{abstract}

Keywords: Wring skill, Descriptive Text, Video

\section{INTRODUCTION}

Writing as a part of other skills in learning English is very important for everyone, as it is that know English is used as an international language in the world a nowdays. Many people think that learning English is still considered as a difficult subject, especially in leraning writing. This statement is reinforced by Blanchard and Root (1998: 1) as cited in Yulianti, Nuraeni, \& Parmawati, (2019) learning to write in a new language is not always easy. The difficulty does not only lie a found translating and pouring the idea into written form, but also, the use of appropriate grammar and suitable vocabulary must be considered in expressing ideas into text so that readers can understand was written.

It is expented that writing can make students can share experiences, ideas, and information. By writing students can express themselves so that writing becomes a pleasant activity. In writing there are aspects that must be considered such as grammar, organization, spelling, punctuation and vocabulary that can affect the contents of the writing. Brown (2004) in Eliyawati (2020)" the writing product should fulfill some criteria, such as organization, content, grammar, vocabulary, and mechanics". It is stated that writing is a complex process in conveying experiences, ideas and information. In practice, although writing is a fun activity many students find it difficult to begin to write. Based on the researchers' previous research this condition is influenced by the lack of students' knowledge of mastering in grammar, vocabulary, the use of 
thanguation In writing which is still messy, and the use of appropriate than situastion. punctuation is not appropriate.

From the facts above it can be seen that problem is not only by students but also by the teacher. Some of the problems are the use of approaches methods, techenique, and even media are often not apperopiate. The result of choosing this an appropriate thing can make students and able to understand the material. In other words, teachers should facilite suitable, approcies method tecnique and media so that students can easly understand the materials in teaching-learning proses. There are different kinds of media which can be used to support teachers in teaching writing. One of which is the use of video. By using video the students can pay attention to the material in more detail, because students can see pictures, can listen to the conversation and can wacth the character and expression on the video.

In addition, if the students have not understood the content of the material dilivered on the video, they can play the video back. This means the students will have a chance to understand more about the material as it is cited by Austin \& Haley (2004) in Fitriatun (2019) "video techniques help the learners to get the information by putting them in real-life context". It is explained furthermore students can more easily understand by watching video. Therefore, using video as a media in learning to write is expected to increase understanding in the writing process.

In learning writing, There are several types of texts, those are descriptive text, narrative, recalculation, procedures, reports, exposition, explanations, anecdote. This research chosen one the of texts that is descriptive text. According to Wyrick (1987:227) as cited in Pratiwi, Aulia, \& Suryani (2019) states, "The writer of description creates a word picture of persons, places, objects, and emotions using a careful selection of detail to make an impression on the reader". In writing descriptive text it will begin with the explanation about general information followed by a more detailed object. Blaylock (2006:1) in Royani \& Sadiah, (2019) state that descriptive text has two main parts; The first is identification of how the object is described and the second is a description of the object described by the writer. Apendi \& Mulyani (2020) taken from Wignell (1994) explains furthermore that "descriptive text is a text that describes a particular person, place, and things. Rohmat, Nurhaeni, \& Anggraeni (2018) cited from Gerot \& Wignell (1995: 208) state that "formulates some language features of descriptive text, one of them is using clause with attributive and identifying processes".

\section{METHOD}

This research was conducted using descriptive qualitative method Suryana (2010) in Royani \& Sadiah (2019) Descriptive Qualitative research is a research in which the process of analyzing the subject systematically. Descriptive qualitative research focuses on making systematic and accurate descriptions according to the facts of the field. It is stated more that qualitative research is collection data related to events during the research process. In this study the researchers collecting data by using observation sheets and questionnaires. Observations were done in three learning class meetings which was conducted while learning activities. This study was conducted directly by observing the learning process of students in class. The subject of the study consisted of 20 students. This research was conducted in twenty statements , the following is the displayed of the table. 
Table 1.

Observation checklist for the teachers

\begin{tabular}{|c|c|c|c|}
\hline No & Activity & $\begin{array}{l}\text { Yes } \\
(\sqrt{ })\end{array}$ & $\begin{array}{l}\text { No } \\
(-)\end{array}$ \\
\hline 1 & $\begin{array}{l}\text { The researchers opens the calss by greeting and checking the } \\
\text { attendance list of students }\end{array}$ & & \\
\hline 2 & The researchers introduces the topic to students & & \\
\hline 3 & $\begin{array}{l}\text { The researchers pay attention to the material they are studying } \\
\text { seriously }\end{array}$ & & \\
\hline 4 & $\begin{array}{l}\text { The researchers identifies the student's main understanding of } \\
\text { descriptive text }\end{array}$ & & \\
\hline 5 & $\begin{array}{l}\text { The researcher introduces the descriptive language element of the } \\
\text { text to students }\end{array}$ & & \\
\hline 6 & $\begin{array}{l}\text { The researches explains generic structures and adjectives and nouns } \\
\text { to students }\end{array}$ & & \\
\hline 7 & The researchers ask students about descriptive texts & & \\
\hline 8 & The students answer questions from researchers & & \\
\hline 9 & The esearchers provide examples of descriptive text & & \\
\hline 10 & The students give examples of descriptive text & & \\
\hline 11 & The students give a good response to researchers & & \\
\hline 12 & The students take notes to write important information & & \\
\hline 13 & The students take lessons seriously & & \\
\hline 14 & $\begin{array}{l}\text { The researchers apply discovery learning methods in teaching and } \\
\text { learning }\end{array}$ & & \\
\hline 15 & The researchers divide students into groups (pairs) & & \\
\hline 16 & The students discuss with their friends & & \\
\hline 17 & $\begin{array}{l}\text { The researchers provide time for students to work together (create } \\
\text { groups and discuss) }\end{array}$ & & \\
\hline 18 & The researchers give assignments & & \\
\hline 19 & $\begin{array}{l}\text { The esearchers give time for students to submit their questions } \\
\text { related to descriptive text }\end{array}$ & & \\
\hline 20 & The researcher closed the meeting with greetings & & \\
\hline
\end{tabular}

\section{Note}

I First observation teacher

II Second observation teacher

$\sqrt{ } \quad$ Yes

$-\quad$ No


The questionnaires are given to students after all materials were implemented. The questionnaires ware divided into two types Yes/No questions, in which there were four main indicators-relevance, evidence, and satisfaction. The following is the table of the questioners. Source: Adapted from Muhlisin (2018)

Table 2.

Students' responses questionnaire

\begin{tabular}{|c|c|c|c|}
\hline No & Questions & $\begin{array}{l}\text { Yes } \\
(\sqrt{ })\end{array}$ & $\begin{array}{l}\text { No } \\
(-)\end{array}$ \\
\hline 1 & $\begin{array}{l}\text { Does learning to write with video that have been applied make you } \\
\text { have a high willingness to take lessons? }\end{array}$ & & \\
\hline 2 & $\begin{array}{l}\text { Can learning to write with video applied have reduced errors in } \\
\text { learning to write? }\end{array}$ & & \\
\hline 3 & $\begin{array}{l}\text { Does the learning that has been done make it easier for you to } \\
\text { understand the learning material? }\end{array}$ & & \\
\hline 4 & $\begin{array}{l}\text { Does learning to write with video that have been applied make it easy } \\
\text { for you to understand the material being taught? }\end{array}$ & & \\
\hline 5 & $\begin{array}{l}\text { Is learning to write with video that have been applied more interesting, } \\
\text { fun, and not boring? }\end{array}$ & & \\
\hline 6 & $\begin{array}{l}\text { Do you feel the time given by the teacher to understand the material } \\
\text { goes quickly? }\end{array}$ & & \\
\hline 7 & $\begin{array}{l}\text { By using video that have been applied, are you motivated to get better } \\
\text { grades? }\end{array}$ & & \\
\hline 8 & $\begin{array}{l}\text { Does learning to write with video that have been applied can } \\
\text { enhanched your logical development individually? }\end{array}$ & & \\
\hline 9 & $\begin{array}{l}\text { Do you feel more valued when expressing your opinions when } \\
\text { studying in class? }\end{array}$ & & \\
\hline 10 & $\begin{array}{l}\text { Are you more courageous in expressing your opinion in the learning } \\
\text { process in the classroom? }\end{array}$ & & \\
\hline
\end{tabular}

\section{RESULTS AND DISCUSSION}

\section{Results}

The section shows the results of the researchers. After analyzing the observation checklist and the students' response questionnaires, the researchers obtain the results as follows;

Table 3.

Results of stundents' observation checklist

\begin{tabular}{|c|c|c|c|c|c|c|c|}
\hline \multirow{2}{*}{ No } & \multirow{2}{*}{ Activity } & \multicolumn{2}{|c|}{$\begin{array}{c}\text { Meeting } \\
1\end{array}$} & \multicolumn{2}{|c|}{$\begin{array}{c}\text { Meeting } \\
2\end{array}$} & \multicolumn{2}{|c|}{$\begin{array}{l}\text { Meeting } \\
3\end{array}$} \\
\hline & & $\mathbf{I}$ & II & $\mathbf{I}$ & II & $\mathbf{I}$ & II \\
\hline 1 & $\begin{array}{l}\text { The researchers opens the calss by greeting and } \\
\text { checking the attendance list of students }\end{array}$ & $\sqrt{ }$ & $\sqrt{ }$ & $\sqrt{ }$ & $\sqrt{ }$ & $\sqrt{ }$ & $\sqrt{ }$ \\
\hline 2 & The researchers introduces the topic to students & $\sqrt{ }$ & $\sqrt{ }$ & $\sqrt{ }$ & $\sqrt{ }$ & $\sqrt{ }$ & $\sqrt{ }$ \\
\hline 3 & $\begin{array}{l}\text { The researchers pay attention to the material they are } \\
\text { studying seriously }\end{array}$ & $\sqrt{ }$ & $\sqrt{ }$ & - & $\sqrt{ }$ & $\sqrt{ }$ & $\sqrt{ }$ \\
\hline 4 & $\begin{array}{l}\text { The researchers identifies the student's main } \\
\text { understanding of descriptive text }\end{array}$ & $\sqrt{ }$ & $\sqrt{ }$ & $\sqrt{ }$ & $\sqrt{ }$ & $\sqrt{ }$ & $\sqrt{ }$ \\
\hline
\end{tabular}




\begin{tabular}{|c|c|c|c|c|c|c|c|}
\hline 5 & $\begin{array}{l}\text { The researcher introduces the descriptive language } \\
\text { element of the text to students }\end{array}$ & $\sqrt{ }$ & $\sqrt{ }$ & $\sqrt{ }$ & $\sqrt{ }$ & $\sqrt{ }$ & $\sqrt{ }$ \\
\hline 6 & $\begin{array}{l}\text { The researches explains generic structures and } \\
\text { adjectives and nouns to students }\end{array}$ & $\sqrt{ }$ & $\sqrt{ }$ & $\sqrt{ }$ & $\sqrt{ }$ & $\sqrt{ }$ & $\sqrt{ }$ \\
\hline 7 & The researchers ask students about descriptive texts & $\sqrt{ }$ & $\sqrt{ }$ & $\sqrt{ }$ & $\sqrt{ }$ & $\sqrt{ }$ & $\sqrt{ }$ \\
\hline 8 & The students answer questions from researchers & $\sqrt{ }$ & $\sqrt{ }$ & $\sqrt{ }$ & $\sqrt{ }$ & $\sqrt{ }$ & $\sqrt{ }$ \\
\hline 9 & The esearchers provide examples of descriptive text & $\sqrt{ }$ & $\sqrt{ }$ & $\sqrt{ }$ & $\sqrt{ }$ & $\sqrt{ }$ & $\sqrt{ }$ \\
\hline 10 & The students give examples of descriptive text & - & - & $\sqrt{ }$ & $\sqrt{ }$ & $\sqrt{ }$ & $\sqrt{ }$ \\
\hline 11 & The students give a good response to researchers & $\sqrt{ }$ & $\sqrt{ }$ & $\sqrt{ }$ & $\sqrt{ }$ & $\sqrt{ }$ & $\sqrt{ }$ \\
\hline 12 & $\begin{array}{l}\text { The students take notes to write important } \\
\text { information }\end{array}$ & $\sqrt{ }$ & $\sqrt{ }$ & $\sqrt{ }$ & $\sqrt{ }$ & $\sqrt{ }$ & $\sqrt{ }$ \\
\hline 13 & The students take lessons seriously & $\sqrt{ }$ & $\sqrt{ }$ & $\sqrt{ }$ & - & $\sqrt{ }$ & $\sqrt{ }$ \\
\hline 14 & $\begin{array}{l}\text { The researchers apply discovery learning methods in } \\
\text { teaching and learning }\end{array}$ & $\sqrt{ }$ & $\sqrt{ }$ & $\sqrt{ }$ & $\sqrt{ }$ & $\sqrt{ }$ & $\sqrt{ }$ \\
\hline 15 & The researchers divide students into groups (pairs) & $\sqrt{ }$ & $\sqrt{ }$ & $\sqrt{ }$ & $\sqrt{ }$ & $\sqrt{ }$ & $\sqrt{ }$ \\
\hline 16 & The students discuss with their friends & $\sqrt{ }$ & $\sqrt{ }$ & $\sqrt{ }$ & $\sqrt{ }$ & $\sqrt{ }$ & $\sqrt{ }$ \\
\hline 17 & $\begin{array}{l}\text { The researchers provide time for students to work } \\
\text { together (create groups and discuss) }\end{array}$ & $\sqrt{ }$ & $\sqrt{ }$ & $\sqrt{ }$ & $\sqrt{ }$ & $\sqrt{ }$ & $\sqrt{ }$ \\
\hline 18 & The researchers give assignments & $\sqrt{ }$ & $\sqrt{ }$ & $\sqrt{ }$ & $\sqrt{ }$ & $\sqrt{ }$ & $\sqrt{ }$ \\
\hline 19 & $\begin{array}{l}\text { The esearchers give time for students to submit their } \\
\text { questions related to descriptive text }\end{array}$ & $\sqrt{ }$ & $\sqrt{ }$ & $\sqrt{ }$ & $\sqrt{ }$ & $\sqrt{ }$ & $\sqrt{ }$ \\
\hline 20 & The researcher closed the meeting with greetings & $\sqrt{ }$ & $\sqrt{ }$ & $\sqrt{ }$ & $\sqrt{ }$ & $\sqrt{ }$ & $\sqrt{ }$ \\
\hline
\end{tabular}

\begin{tabular}{cll}
\hline & & Note \\
I & First observation teacher & \\
II & Second observation teacher & \\
$\sqrt{ }$ & Yes \\
- & No \\
\hline
\end{tabular}

Based on the steps in the lesson plan

Based on the results of the above data, it can be explained the results at the first meeting. The first teacher-observer and the second teacher-observer stated that the researchers had followed the composition of the scenarios. However, students have not been able to give examples related to descriptive text sentences. At the second meeting, the first teacher-observers noticed that the researchers had paid attention to the material but did not take it seriously. Whereas the second teacher-observer had seen that some students were less serious in participating in learning. at the third meeting, the first teacher-observers and the second teacher-observers saw that the researchers had followed all the statements during the teaching and learning process.

The results of teacher-observation sheet analysis data state that researchers from beginning to end have opened learning by greeted and checked the attendance list of students. The researchers have introduced the topic and learning objectives for students before learning begins. The researchers have explained the description text to students and examined student learning outcomes seriously, researchers have identified the main understanding of students related to the description text. In addition, the researchers introduced the description text model and explained the generic structure and description text feature to the students, the researchers asked the students about their understanding of the descriptive text, researchers had seen the 
answers from the students based on the researcher's questions, researchers had provided examples of the description text sentence, students have described respond well to researchers and had taken notes important information, students have followed the lessons and understood them seriously, researchers have applied methods by using video as a media in teaching writing descriptive text, researchers have divided students into forms study groups, students have discussed and shared understanding with their group friends and researchers have given time to students to collaborate with their respective groups in carryed out the tasks given by researchers, researchers gave time to students to understand work out the assignment and then submit the results of their analysis related to the descriptive text to the researcher, the researcher has closed the learning by provided learning motivation and closed with regards.

From the explanation above it can be shown that during the implementation of learning writing. It can be explained from the three meetings that there was a change in the role of researchers in teaching and changes in students in learning to write. For example, at first, several scenarios did not work in the implementation process. However, from each meeting, there was a change in scenarios that could be implemented by the researchers. Likewise, the change of students in the activity of learning, at each meeting the level of student activity increased for the bette.

The following is the result of the students responses in the process of teaching writing used video as media;

Table 4.

Results of students' questionnaire

\begin{tabular}{|c|c|c|c|c|}
\hline \multirow{2}{*}{ Indicators } & \multirow{2}{*}{$\begin{array}{c}\text { Item } \\
\text { Numbers }\end{array}$} & \multicolumn{2}{|c|}{ Percentage of Answer } & \multirow{2}{*}{ Total } \\
\hline & & Yes & No & \\
\hline \multirow{4}{*}{ Attention } & 1 & $100 \%$ & $0 \%$ & $100 \%$ \\
\hline & 2 & $70 \%$ & $30 \%$ & $100 \%$ \\
\hline & 3 & $100 \%$ & $0 \%$ & $100 \%$ \\
\hline & 4 & $100 \%$ & $0 \%$ & $100 \%$ \\
\hline \multirow{2}{*}{ Relevance } & 5 & $100 \%$ & $0 \%$ & $100 \%$ \\
\hline & 6 & $90 \%$ & $10 \%$ & $100 \%$ \\
\hline \multirow{2}{*}{ Confidence } & 7 & $100 \%$ & $0 \%$ & $100 \%$ \\
\hline & 8 & $90 \%$ & $10 \%$ & $100 \%$ \\
\hline \multirow{2}{*}{ Satisfaction } & 9 & $80 \%$ & $20 \%$ & $100 \%$ \\
\hline & 10 & $70 \%$ & $30 \%$ & $100 \%$ \\
\hline
\end{tabular}

From the table above could explain the results of the questionnaire containing the students' responses in the learning process. In the first indicator (attention) all students agreed with the statement that learning by using video as a medium in learning writing descriptive texts that have been applied made students in learning become motivated and have a higher willingness to attend learning. almost some students disagreed with the statement that writing using video as media could reduce errors in learning writing. All students agreed with the statement that learning to use video as a medium for learning made it easy for students to understand learning material. Likewise in the statement in the use of video media in learning to write that has been applied, all students state their statement that understanding the material being taught becomes easier. Indicators at the point of the (relevance) of all students stated that using video media in learning to write was more interested, enjoyable, and not boring. Some students from all students stated their statement that students felt the time given by the teacher to understand the material was very fast. Indicators of (confidence) of all students stated their statement that by using video media, students became motivated to get better grades and there were some students 
stated their statement that the use of video in learning writing could improve students' skills. In the indicators of (stratification), there were some students stating statements disagreed with statements that students feel valued when expressing opinions while studying in class and some students declare disagreed with statements that become bolder in expressing their opinions in the learning process in class.

Based on the results of the questionnaire above it could explain related to student responses to learning writing that has been implemented, from each indicator there was a share of student responses that answer all questions. That students respond well to the use of video media in learning to write a descriptive text..

\section{Discussion}

Based on the results of the data analysis of the observation list for three meetings can be explained that the implementation of teaching writing descriptive text using video as a medium can work well. This can be explained based on the observation sheet which is the result of the observations of the first teacher observers and second teacher observers on the implementation of teaching conducted by researchers. At the first meeting, the researcher performed his task based on a planned scenario. However, the observations of the first teacher-observer and the second teacher-observer stated that researchers have not fully followed the existing scenarios, some scenarios could not be implemented by researchers. Among them were at the tenth point where students could not give examples of text description sentences as written in the scenarios.

At the second meeting, researchers applied all scenarios in teaching writing using video media. However, there were differences of opinion expressed by the first teacher-observers and second teacher-observers related to the implementation of the scenarios by the researchers. According to the first teacher-observer, the researchers did not apply the scenarios contained in the third point ie the researcher did not pay attention to the material they were studying seriously, while the second teacher-observer stated that students did not take the lesson seriously as in the scenarios on the thirteenth point. At the third meeting, the first teacher-observer and the second teacher-observer stated that the scenarios implemented by the researchers had followed all the scenarios prepared. The researchers could run all learning scenarios of writing descriptive text well.

Seeing from the explanation of the scenarios implementation process applied by the researchers with the results stated by two teacher-observers stated that researchers at each meeting improved the quality of teaching by applied all the scenarios correctly done. For examples from the first and second meetings, there were still scenarios that were not done but at the third meeting all scenarios could be implemented.

The researcher had made scenarios based on descriptive text material that will be taught. This video media had applied in the seventh grade of junior high school. Video media was chosen because it could facilitate students in paying attention to the material to be able to describe it in writing. Before learning is done, researchers made student study groups consisting of 4-5 students in one group. Then the teacher presents the material in the form of video shows aimed at students could analyze and understand the material. After that, students were allowed to describe what they had seen in the video and discussed exchange opinions and shared ideas with their group friends, and gave the task to write back into writing according to what they understand. This is the final form given by researchers in the process of implementing learning writing descriptive text. 
in accordance with the results of learning writing descriptive text using video as media. There were questionnaire results containing students 'responses stating their responses regarding the implementation video as a medium to enhance the logical development of students' writing learning skills. Based on a questionnaire containing student responses, the attention indicator has the willingness to take lessons after the implementation of video media in the writing class. Almost all students from the total students stated that by using video media in learning writing, students can reduced errors in writing. All students stated their statement that by using video media they could easily explore the material and all students stated that after implementing using video as media in learning writing, students understood the material being taught.

After the video media implementation was used, all students were stating that they did not feel bored and the learning process became more interested and enjoyable. a few students out of all students disagree that the time during learning becomes shorter and faster. All students stated that the time given by the researcher was sufficient to understand the material..

Besides, the use of video media made students more confident in learning writing. All students stated that they were motivated to get better grades in learning writing and a few of all students stated that after the learning process of writing using video media students could improve their logical development in writing. During the learning process, students feel satisfied when presented learning outcomes in front of the class. almost all students stated that they felt valued when expressing their writing. some students disagree with the statement of students more daring in expressing their learning outcomes.

Based on the questionnaire, it can be seen how students' responses to the teaching of writing descriptive text using video as media have increased students attention in the learning process of writing. An examples were that all students expressed motivation and almost all students dared to express their opinions. These results state that students respond very well to learning writing using video as a media. Based on the findings of research results from Rapiyadi (2018). It can be concluded that the use of video as a medium in learning to write descriptive text can be categorized into good categories.

\section{CONCLUSION}

From the previous explained above it can be concluded with the findings of research that has been done. The scenarios have been applied very well in the implementation that has been done by researchers in the learning process. This study got a good response from students in following during the process of learning to write in class, students can be motivated and the level of attending lessons increases, because in the learning process students do not feel bored, and students feel happy and easy to understand the material being taught.

\section{ACKNOWLEDGMENTS}

First of all thanks to ALLAH S.W.T for His mercy and guidence in giving me strength to complete this article. The gratitude is delivered to my supervisor for all of this support and guidence in helping me to finish my article. Then, I would like to thanks to my parents. At last, this research can be useful for the reader and other researchers. 


\section{REFERENCES}

Apendi, T. L., \& Mulyani, E. R. (2020). The analysis of Transitivity process of Students' Descriptive Text, 3(3), 359-366.

Eliyawati, E. (2020). Improving students' ability to write narrative texts using pictures. ALASASIYYA: Journal Of Basic Education, 4(2), 37. https://doi.org/10.24269/ajbe.v4i2.2421

Fitriatun, E. (2019). Student's Speaking Skill in Oral Descriptive Text by Using Video at Tenth grade in SMA NEGERI 1 NAMLEA. Journal of Chemical Information and Modeling, 53(9), 1689-1699. https://doi.org/10.1017/CBO9781107415324.004

Muhlisin, Ahmad. 2018. “Unnes Science Education Journal Analysis of Students' response of The implementation of Rms (Reading, mind mapping, and sharring) Learning Model in Philosophy of Science." Usej 7(1): 13-18.

Pratiwi, R., Aulia, R. P., \& Suryani, L. (2019). an Error Analysis on Using Personal Pronouns in Writing Descriptive Text. PROJECT (Professional Journal of English Education), 2(5), 608. https://doi.org/10.22460/project.v2i5.p608-615

Rapiyadi, Muhammad et al. 2018. "The influence of using Video to Students' Skills in writing Descriptive text." 3(3).

Rohmat, N., Nurhaeni, N., \& Anggraeni, A. (2018). Transitivity Analysis of Tenth Grade Students' Descriptive Text. PROJECT (Professional Journal of English Education), 1(3), 295. https://doi.org/10.22460/project.v1i3.p295-302

Royani, S., \& Sadiah, S. (2019). an Analysis of Grammatical Errors in Students' Writing Descriptive Text. PROJECT (Professional Journal of English Education), 2(6), 764. https://doi.org/10.22460/project.v2i6.p764-770

Yulianti, S., Nuraeni, S., \& Parmawati, A. (2019). Improving Students'writing Skill Using Brainswriting Strategy. Project (Professional Journal Of English Education), 2(5), 714721. https://doi.org/10.22460/project.v2i5.p714-721 